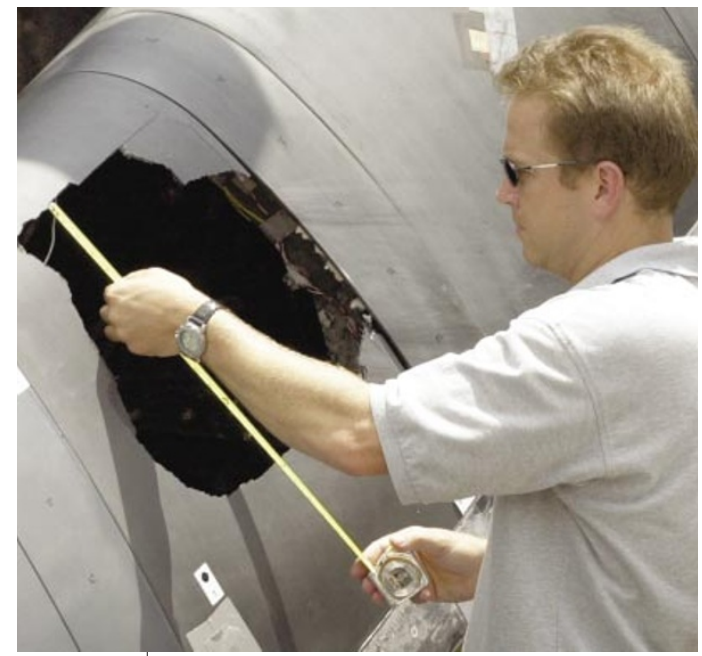

This NASA test shows that insulating foam could have punched a similar hole in Columbia's wing.

also suggested that the White House will unveil a new space initiative - possibly a return to the Moon - within the next few months. Certainly, the agency needs to find itself a convincing new vision, and fast.

Tony Reichhardt

\section{Membrane proteins}

\section{Channel voyager makes waves}

They are the gatekeepers of the cell, responsible for the movement of ions across its outer membrane. And 2003 was the year in which the scientist who painstakingly deciphered many of their structures received the ultimate honour for his work - just months after his latest data challenged orthodox views in the field.

Beginning with a landmark paper ${ }^{1}$ published in 1998, Rod MacKinnon of Rockefeller University in New York has determined the detailed structures of several important ion channels in the cell membrane $e^{2-6}$. Many of his colleagues thought he was embarking on a fool's errand, as proteins embedded in lipid membranes are notoriously difficult to crystallize for X-ray structural analysis. The magnitude of his achievement helps to explain why he was awarded a share of this year's Nobel Prize in Chemistry - a remarkably rapid response from the usually conservative awarding committee.

Indeed, ion channels have not yet yielded all of their secrets, and it was in investigating a remaining mystery that MacKinnon this year ignited a heated debate. Among the most important ion channels, involved in regulating neural impulses, are potassium channels that can be switched on and off according to the voltage across a cell's membrane. In May, MacKinnon's group published the first crystal structure of one of these 'voltage-gated' potassium channels ${ }^{7,8}$. "It's a major breakthrough," comments electrophysiologist Chris Miller of Brandeis University in Waltham, Massachusetts, one of MacKinnon's early mentors.

In the absence of a detailed structure, researchers interested in such channels had used electrophysiological and molecular data to develop a mechanism for voltage gating. Voltage-gated potassium channels were known to consist of four identical protein subunits around a central core, and most researchers had assumed that the voltagesensitive domains would be situated in the heart of each subunit. They were thought to undergo delicate, screw-like movements in response to changes in voltage, allowing potassium ions to rush through.

In contrast, MacKinnon's structure places the voltage sensors on the exterior of each subunit, extending into the cell membrane. According to his suggested mechanism, the sensors open the channel by heaving through the membrane in large, paddle-like strokes - more like weightlifting than the molecular ballet envisaged earlier.

Critics claim that MacKinnon's mechanism is unrealistic. "Previous and continuing experimental studies suggest that the paddle model will not hold up," says electrophysiologist Richard Horn of Jefferson Medical College in Philadelphia.

But MacKinnon is undaunted. "I think that these new ideas, which are based on very solid structural and functional data, are correct," he asserts.

\section{Alison Abbott}

$$
\begin{aligned}
& \text { 1. Doyle, D. A. et al. Science 280, 69-77 (1998). } \\
& \text { 2. Zhou, M., Morais-Cabral, J. H., Mann, S. \& MacKinnon, R. } \\
& \text { Nature 411, 657-661 (2001). } \\
& \text { 3. Morais-Cabral, J. H., Zhou, Y. \& MacKinnon, R. Nature 414, } \\
& \text { 37-42 (2001). } \\
& \text { 4. Zhou, Y., Morais-Cabral, J. H., Kaufman, A. \& MacKinnon, R. } \\
& \text { Nature 414, } 43-48 \text { (2001). } \\
& \text { 5. Dutzler, R., Campbell, E. B., Cadene, M., Chait, B. T. \& } \\
& \text { MacKinnon, R. Nature 415, 287-294 (2002). } \\
& \text { 6. Jiang, Y. et al. Nature 417, 515-522 (2002). } \\
& \text { 7. Jiang, Y. et al. Nature 423, 33-41 (2003). } \\
& \text { 8. Jiang, Y., Ruta, V., Chen, J., Lee, A. \& MacKinnon, R. } \\
& \text { Nature 423, 42-48 (2003). }
\end{aligned}
$$

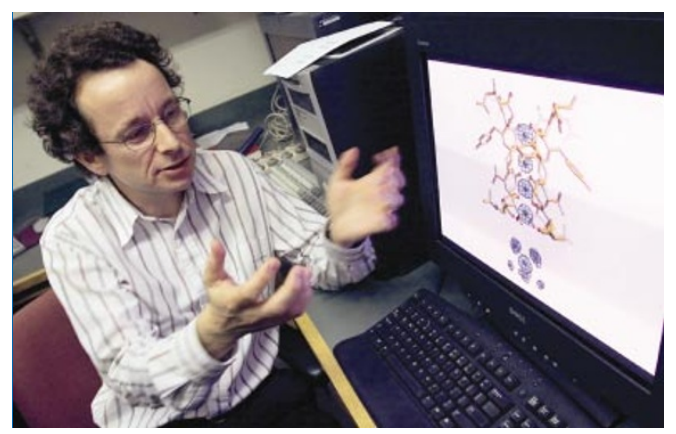

Rod MacKinnon has sparked dispute over his protein studies.
WATCHTHIS SPACE

Send in the clones

The year opened with stories of virgin birth. The Raelian cult, which maintains that the first humans were created by aliens, claimed to have produced its own baby clones. Italian fertility specialist Severino Antinori also said he had women volunteers carrying cloned fetuses. But no clone has been brought forth. The United Nations, meanwhile, debated motions to ban human cloning for reproduction and for research. But it was a similar story of build-up without birth - in the end, members agreed to put the decision off for another year.

\section{Physics heavyweights}

America's hopes of finding the Higgs boson - a particle that is involved in lending mass to other objects - in the Tevatron collider at Fermilab in Illinois were dashed this summer. Problems with the collider make it unlikely to generate enough collisions between protons and antiprotons to spy the particle. The Large Hadron Collider at CERN, near Geneva, which is scheduled to begin operating by 2007 , could offer our best chance of snaring the Higgs.

\section{Water, water everywhere}

It was the International Year of Freshwater. But the World Water Forum in Kyoto, Japan, this spring came up with little to solve the world's problems with this critical natural resource. It did not declare access to clean water a human right; neither did it demand that countries negotiate treaties on sharing rivers. The United Nations' goal of halving the proportion of people without access to safe drinking water and sanitation by 2015 seems a remote prospect.

\section{Off the menu}

The prospect of Europeans growing and eating large amounts of genetically modified (GM) food remains as remote as ever. Strict European Union laws on the need to label and trace GM crops were passed this summer, which many observers thought would ease the way for the approval of new transgenic crops. But when member states met in December to discuss approving one such crop for sale, the vote remained split. So an unofficial moratorium on new licences stays in place, at least until ministers meet next spring.

\section{Free for all}

Will the scientific literature in future be dominated by journals that do not charge their readers? That is the goal of the 'open-access' movement, which argues that the costs of publishing should be borne up front by those who fund research, rather than those who want to read about it. Open-access journals, which charge publication fees, have been proliferating over the past few years. October saw the launch of the most prominent, Public Library of Science Biology, which is competing for top biology papers with Nature, Science and Cell. 